\title{
Cathode development for Alkaline Fuel Cells based on a Porous Silver Membrane
}

\author{
F. Bidault, A. Kucernak ${ }^{\dagger}$ \\ Department of Chemistry, Imperial College London, UK
}

\begin{abstract}
:
\end{abstract}
Porous silver membranes were investigated as potential substrates for alkaline fuel cell cathodes by the means of polarisation curves and electrochemical impedance spectroscopy measurements. The silver membranes provide both electrocatalytic function, mechanical support and a means of current collection. Improved performance, compare to a previous design, was obtained by increasing gas accessibility (using Teflon AF instead of PTFE suspension) and by adding a catalyst $\left(\mathrm{MnO}_{2}\right.$ or $\left.\mathrm{Pt}\right)$ in the membrane structure to increase the cathode activity. This new cathode design performed significantly better $\left(\sim 55 \mathrm{~mA} \mathrm{~cm}{ }^{-2}\right.$ at $0.8 \mathrm{~V}, \sim 295 \mathrm{~mA} \mathrm{~cm}^{-2}$ at $0.6 \mathrm{~V}$ and $\sim 630 \mathrm{~mA} \mathrm{~cm}^{-2}$ at $0.4 \mathrm{~V}$ versus RHE) than the previous design $(\sim 30 \mathrm{~mA}$ $\mathrm{cm}^{-2}$ at $0.8 \mathrm{~V}, \sim 250 \mathrm{~mA} \mathrm{~cm}^{-2}$ at $0.6 \mathrm{~V}$ and $\sim 500 \mathrm{~mA} \mathrm{~cm}^{-2}$ at $0.4 \mathrm{~V}$ ) in the presence of 6.9 $\mathrm{M} \mathrm{KOH}$ and oxygen (1 $\mathrm{atm}(\mathrm{abs}))$ at room temperature. The hydrophobisation technique of the porous structure and the addition of an extra catalyst appeared to be critical and necessary to obtain high performance. A passive air-breathing hydrogenair fuel cell constructed from the membranes achieves a peak power density of 65

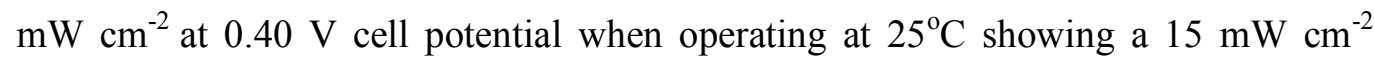
improvement compare to the previous design.

Keywords: Alkaline fuel cell; gas diffusion electrode; cathode; manganese oxide; silver membrane.

\footnotetext{
${ }^{\dagger}$ Corresponding author. Tel.: +44 (0)20 75945831

E-mail address: a.kucernak@imperial.ac.uk.
} 


\section{Introduction}

Recently, there has been a resurgence of interest in alkaline fuel cells (AFCs) [1-4]. Since AFCs do not require precious metal catalysts, they have the potential for lower cost mass production, compared to the other main low temperature fuel cell technology, the proton exchange membrane fuel cells (PEMFCs) [5]. AFCs can be constructed with a liquid [6] or solid electrolyte [7] using gas diffusion electrodes. Special attention on the cathode is required because it is where most of the cell performance losses occur [8]. AFC cathodes usually consist of several PTFE-bonded carbon layers applied onto a metal mesh which is used as the current collector. The catalyst is commonly supported on a high surface area carbon substrate $[9,10]$. The oxygen reduction reaction in alkaline media is more facile than in acid media, making the use of catalyst materials less expensive than platinum possible [11]. Silver has the highest electrical conductivity of any element and is approximately 100 times less expensive than platinum. Moreover, silver is one of the most active catalysts for the oxygen reduction reaction (ORR), even competitive to $\mathrm{Pt}$ in highly concentration alkaline media $[12,13]$, and competitive on a cost/performance ratio [14]. Oxygen cathodes loaded with Ag have also shown a longer lifetime over Pt based cathodes (3 years compare to 1 year for $\mathrm{Pt}$ ) under practical chlor-alkali electrolysis conditions $[15$, 16]. The impregnation of $\mathrm{Ag}$ onto carbon support via the in situ reduction of $\mathrm{AgNO}_{3}$ has been shown to produce very fine catalyst particles, resulting in high surface area required catalyst for optimal cathode performance [17]. Another way to obtain high surface area silver catalyst is the Raney approach, which involves leaching aluminium out of an aluminium/silver alloy using $\mathrm{KOH}$ [18]. 
The properties of silver present opportunities for the development of new electrode designs. The authors have previously shown how silver plated nickel foam can be used as an effective electrode substrate [19]. The silver plated foam provided improved current collection compare to bare nickel foam; however, the catalytic activity was limited due to the low surface area of the open cell structure of the foam. The addition of an extra catalyst layer was necessary in order to obtain improved performance, especially at low overpotential [20].

Porous silver membranes are mainly used in a variety of filtration applications where the antimicrobial and antibacterial properties of silver make them a very efficient filtration system [21-25]. Porous silver membranes offer the potential for a new cathode design that does not use a carbon support. This is beneficial since the commonly used carbon supports degrade in alkaline media, so affecting fuel cell lifetime [9]. Silver membranes are available with small pores size (micron range) and high porosity, resulting in high surface area structures. These properties are particularly useful in AFCs in which silver membranes can provide catalyst, mechanical support and a means of current collection. Parametric studies of the performance of electrodes as a function of pore size were performed in a previous work where cathodes were developed using a PTFE suspension as the hydrophobic agent [26].

This work builds on that previously published study [26] and shows how the use of a new hydrophobic agent and the introduction of an extra catalyst into the cathode structure can significantly improve electrochemical performance. Electrochemical impedance spectroscopy (EIS) is used as a diagnostic technique to expose the source of losses in the cathode. 


\section{Experimental}

\subsection{Electrode Preparation}

Silver metal membranes from Sterlitech (Purity: 99.97\%, of $50 \mu \mathrm{m}$ nominal thickness) were used as cathode substrates, Fig. 1. The pore size of available membranes ranges from 0.2 to $5.0 \mu \mathrm{m}$ but for this work only membranes with 0.2 ,

\subsection{5 and $0.8 \mu \mathrm{m}$ pore size were used.}

(a)

(b)

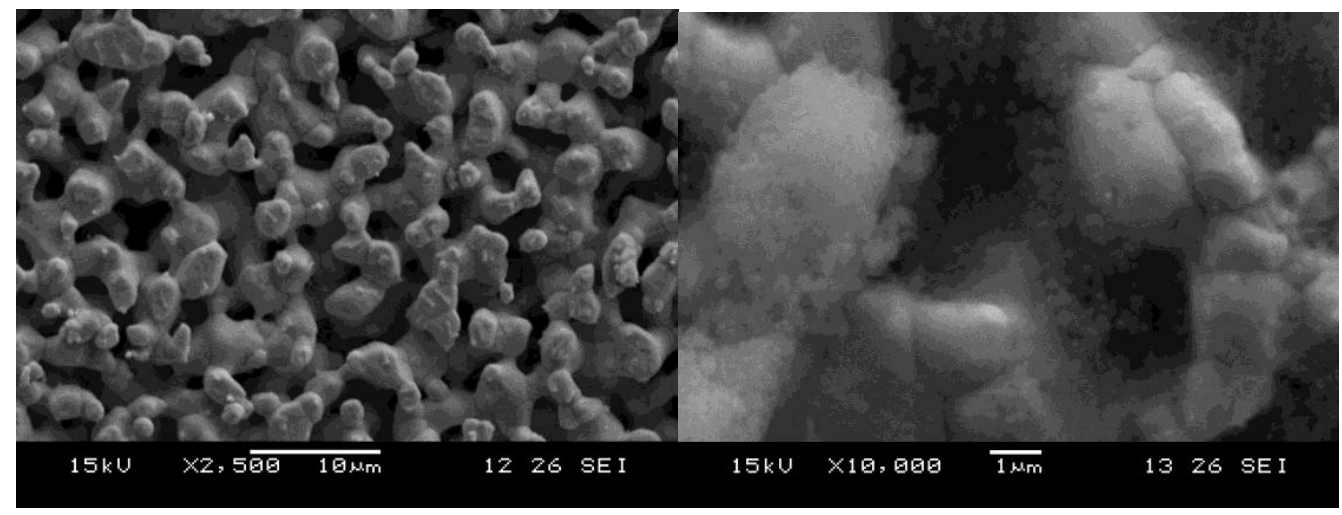

Figure 1: Scanning electron microscope image showing the porous structure of silver membranes without (a) and with PTFE (b).

In the previous work [26], hydrophobisation of the membranes was achieved using polytetrafluoroethylene (PTFE) dispersion which was applied by pipette directly onto one side of the membrane. The PTFE deposition was applied in a two step process. In the first step, a loading was applied that penetrates into the membrane body, this was then allowed to dry at room temperature, after which a second PTFE loading was applied which does not penetrate the membrane but stays on the membrane surface. In the following discussion we refer to the two sides of the membrane as the reactant side (i.e. the side which faces the flowing reactant) and the catalyst side (i.e. the side that faces the electrolyte). 
In the present work, two alternative methods were tried for the fabrication of the gas diffusion layer (GDL). The first method consisted of applying onto the reactant side of the silver membrane a a solution composed of ammonium bicarbonate (Analar, Sigma Aldrich) dissolved in PTFE dispersion (60 wt. \% dispersion in water, Sigma Aldrich) with a mass ratio of 4:1 (PTFE dispersion:solid ammonium bicarbonate) to provide a PTFE loading of $10 \mathrm{mg} \mathrm{cm}^{-2}$. This was then allowed to dry at room temperature for 3 hours. The electrode was then sintered in air at $320^{\circ} \mathrm{C}$ for $30 \mathrm{~min}$ during which the ammonium bicarbonate was volatilised leaving a more porous structure. The second method consisted on applying a $1 \mathrm{wt} \%$ solution of Telfon AF (grade 1600, Dupont DeNemour) dissolved in FC40 (Sigma Aldrich) by pipette directly onto the reactant side of the electrode to produce a Teflon AF loading of $\sim 1$ $\mathrm{mg} \mathrm{cm}{ }^{-2}$. Teflon AF is a type of amorphous fluoropolymer, and was tried as a GDL component as it is soluble in perfluorinated solvents allowing the production of a highly uniform thin film after its deposition onto the substrate. When using Teflon AF as the GDL hydrophobisation agent, no sintering step was necessary and the electrode only needed to be dried at room temperature for $30 \mathrm{~min}$.

Manganese dioxide was used to increase the activity of the cathode. It was chosen because of its relatively low cost and high activity towards the oxygen reduction reaction in alkaline media $[27,28]$. The mechanism of thermal decomposition of manganese nitrate in air has been comprehensively studied by Hussein et al. [29]. According to their work, the precursor is converted to $\mathrm{MnO}_{2}$ at $220^{\circ} \mathrm{C}$, after which it is quantitatively converted to $\mathrm{Mn}_{2} \mathrm{O}_{3}$ at $560^{\circ} \mathrm{C}$. Considering the temperature of the sintering $\left(320^{\circ} \mathrm{C}\right), \mathrm{MnO}_{2}$ is expected to be the major oxide formed. The manganese nitrate (Sigma Aldrich) was added by an impregnation method where the corresponding nitrate and water at a 1:1 mass ratio was applied onto the catalyst side 
of the silver membrane with a pipette. This catalyst deposition was performed after the PTFE deposition step (for both PTFE/pore former and Teflon AF hydrophobic agents) on the reactant side of the electrode to produce a catalyst loading of $\sim 1.5 \mathrm{mg}$

$\mathrm{cm}^{-2}$. The catalyst solution was allowed to dry at room temperature and then the electrode was sintered in air at $320^{\circ} \mathrm{C}$ for 30 min whereupon the metal nitrate was thermally decomposed.

In the case of electrodes containing a Pt catalyst deposit, an ink was prepared composed of $10 \mathrm{mg}$ of $20 \mathrm{wt} \% \mathrm{Pt} / \mathrm{C}$ (Hispec 3000, Alfa Aesar), $1.9 \mathrm{ml}$ of propanol and $0.1 \mathrm{ml}$ of $5 \mathrm{wt} \%$ Nafion solution (DE521, Ionpower Inc, USA). The ink was ultrasonically agitated for $30 \mathrm{~min}$ before $20 \mu \mathrm{l}$ was micro-pipetted onto the catalyst side of the membrane leading to a loading of $20 \mu \mathrm{g} \mathrm{cm}{ }^{-2}$ of Pt. After the Pt ink deposition, the membrane was allowed to dry at room temperature for $30 \mathrm{~min}$. Finally, Teflon AF was applied on the reactant side leading to an electrode fabricated without any sintering step.

The electrolyte used in all experiments was a concentrated potassium hydroxide solution (30 wt. \%) unless otherwise specified. This solution was prepared from 19 $\mathrm{M} \Omega \mathrm{cm}$ deionised water (Millipore, Q10 system) and $\mathrm{KOH}$ pellets (Analar grade, VWR).

\subsection{Electrode characterization}

Electrochemical and impedance measurements (frequency range: $10 \mathrm{kHz}$ to $0.1 \mathrm{~Hz}$, amplitude $0.02 \mathrm{~V}$ rms) were performed using a PGSTAT30 potentiostat (Autolab, EcoChemie Netherlands). All the results presented in this paper are three electrode measurements using a dynamic hydrogen reference electrode from Gaskatel (Hydroflex HREF B01). All electrochemical potentials are henceforth referred to this 
electrode. The surface of the silver membranes was analysed using a scanning electron microscope (JEOL JSM-5610LV).

The catalytic activity of the various silver membranes was measured in a half-cell configuration using a three electrode set-up and a Luggin capillary situated less than $0.5 \mathrm{~mm}$ from the electrode surface and a counter electrode of nickel foam which was 10 times the geometrical surface area of the working electrode, to avoid excessive polarization. Silver membrane cathodes $\left(1 \mathrm{~cm}^{2}\right)$ were floated on the surface of a fresh $\mathrm{KOH}$ solution with the other side exposed to an oxygen (High purity grade N6.0) or air atmosphere through forced convection [30]. Cathodes were polarised after 15 min in contact with the electrolyte under oxygen in a first scan $(0.01 \mathrm{~V} / \mathrm{s})$ from OCV $(1.1$ V) to $0.1 \mathrm{~V}$ for conditioning. All polarization curves shown are the results of a second scan. A third scan was then taken (not shown in this paper) to make sure that the optimum performance was obtained. Impedance spectra were then taken at $0.8 \mathrm{~V}$, still under oxygen at room temperature and atmospheric pressure. Finally, measurements were performed under air.

\subsection{Fuel Cell operation}

Cathodes were tested in a circular $4 \mathrm{~cm}^{2}$ (active area) Hydrogen-air fuel cell utilising $47 \mathrm{~mm}$ diameter silver membrane disks as mechanical support, gas diffusion layer, current collector and catalyst. The fuel cell was constructed using a commercial hydrogen reformate anode from Alfa Aesar (Johnson Matthey Company, $0.4 \mathrm{mg} \mathrm{cm}{ }^{-2}$ Pt, Toray paper GDL) separated with a plastic mesh (1 mm thick, polypropylene, Plastok Associates 1td). Current was collected around the edge of the silver membrane disk, requiring that the current from the centre of the disk flowed $>1 \mathrm{~cm}$ to the external current collector. The KOH solution was $30 \mathrm{wt}$ \% \%, pure hydrogen $(99.999 \%$, 
BOC) was provided on the anode side whereas the cathode side was left open to the laboratory air in self-breathing mode without forced convection at $20^{\circ} \mathrm{C}$. As the cathode was open to the laboratory air, no pressure control was possible. Utilising optimised PTFE loading, the fuel cell did not show any weeping of electrolyte on the cathode side. Fuel cell results are not iR corrected.

\section{Results and discussion}

\subsection{Characterization of silver membranes}

Table 1 summarizes results of physical measurements made on the different silver membranes. The particle retention characteristic is taken from the manufacturer's data sheet, and may be broadly considered to be close to the pore diameter. The porosity was calculated by weighing a known geometric volume of membrane and utilising the density of pure silver. The specific surface area calculated using Eq. 1 relates to an estimation of the surface area considering only the inside of each pore which is assumed to be a long cylinder (tortuosity $=1$ ) where $P$ is the membrane porosity, $\rho$ the silver density and $r$ the radius of the cylinder. This value is clearly a lower limit. It can be seen that silver membranes with 0.2 and $0.8 \mu \mathrm{m}$ have the highest estimated surface area and therefore should give the best performance. This model provides only an approximate assessment of the specific surface area as clearly the tortuosity of the membranes is greater than one, Fig. 1.

$$
A=\frac{2 P}{\rho r(1-P)} \text { Eq. } 1
$$




\begin{tabular}{|c|c|c|c|}
\hline $\begin{array}{c}\text { Particle retention / } \\
\mu \mathrm{m}\end{array}$ & Thickness $/ \mu \mathrm{m}$ & Porosity / \% & $\begin{array}{c}\text { Specific surface } \\
\text { area } / \mathrm{m}^{2} \mathrm{~g}^{-1}\end{array}$ \\
\hline 0.2 & 57 & 26.1 & 0.67 \\
\hline 0.45 & 57 & 33.6 & 0.43 \\
\hline 0.8 & 85 & 54.2 & 0.56 \\
\hline
\end{tabular}

Table 1: Key characteristics of silver membranes

SEM images of the $0.8 \mu \mathrm{m}$ pore size silver membrane surface before and after PTFE deposition are shown in Fig. 1. As can be seen in Fig. 1a, the porosity of the membrane appears to be homogeneous with pores in the micron range. In Fig. 1b, an excess of PTFE can be seen in the centre of the picture with smaller particles in the membrane pores.

The equivalent circuit shown in Fig. 2 was proposed in our previous work [26] to fit the silver membrane cathodes impedance spectrum where $R \Omega$ is the sum of electrolyte resistance (bulk), contact resistances and cell resistances; R1 is the Ohmic resistance of the electrolyte in active pores (or flooded pores) which depends on electrode porosity and wettability and finally R2 is related to kinetics. Similar circuits have already been proposed in the case of cathode [31] and anode [32] in alkaline media.

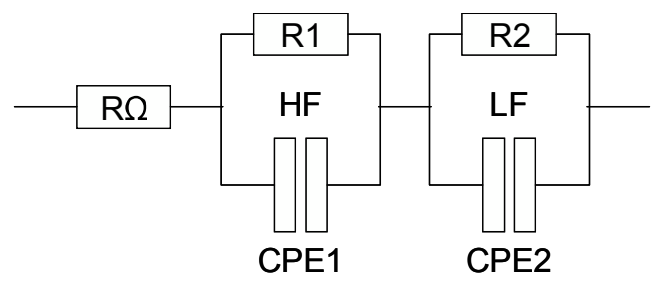

Figure 2: Equivalent circuit of the silver membrane cathode used to fit both the high frequency and low semi-circles. 
The electrolyte uptake measurements were performed by determining the difference in weight of a $1 \mathrm{~cm}^{2}$ section of electrode before and after immersion in $1 \mathrm{M} \mathrm{KOH}$. Excess electrolyte on the electrode surface was removed by gently tapping the electrode before weighing. Electrolyte volume was estimated utilising the density of $1 \mathrm{M} \mathrm{KOH}\left(\rho=1.0464 \mathrm{~g} \mathrm{~cm}^{-3}[33]\right)$

\subsection{Characterization of silver membrane cathodes with PTFE/pore former as hydrophobisation agent}

A $0.8 \mu \mathrm{m}$ pore size silver membrane cathode was prepared with a PTFE coating following the procedure described in the experimental section using ammonium bicarbonate as pore former. The half cell polarization curve was plotted as well as a cathode prepared following the PTFE deposition procedure described in the previous study without the pore former (Fig.3). As can be seen, cathode with the PTFE/ammonium bicarbonate as hydrophobisation agent shows a modest $10-20 \%$ improvement over the cathode without the pore former, especially at high overpotentials ( $\sim 225 \mathrm{~mA} \mathrm{~cm}^{-2}$ at $0.6 \mathrm{~V}$ and $\sim 490 \mathrm{~mA} \mathrm{~cm}^{-2}$ at $0.4 \mathrm{~V}$ compared to $\sim 200$ $\mathrm{mA} \mathrm{cm}$ at $^{-2} 0.6 \mathrm{~V}$ and $\sim 410 \mathrm{~mA} \mathrm{~cm}^{-2}$ at $0.4 \mathrm{~V}$ ). Impedance measurements were performed on both cathodes (Fig.3 inset) which shows a depressed arc at high frequency and a capacitive semi-circle at low frequency. As can be seen, the cathode with the PTFE/pore former exhibits a smaller low frequency capacitive arc compared to the cathode without the pore former. This could be interpreted by the decrease in mass transport resistance due to higher oxygen accessibility to the reaction sites related to the increase in porosity of the hydrophobic layer with the pore former. Both cathodes show the same depressed high frequency capacitive semi-circle which was expected since porosity of the electrode is the same. It also shows that the 
hydrophobic layer with the pore former offers the same hydrophobocity as the hydrophobic layer without the pore former while improving oxygen accessibility to the reaction active sites.

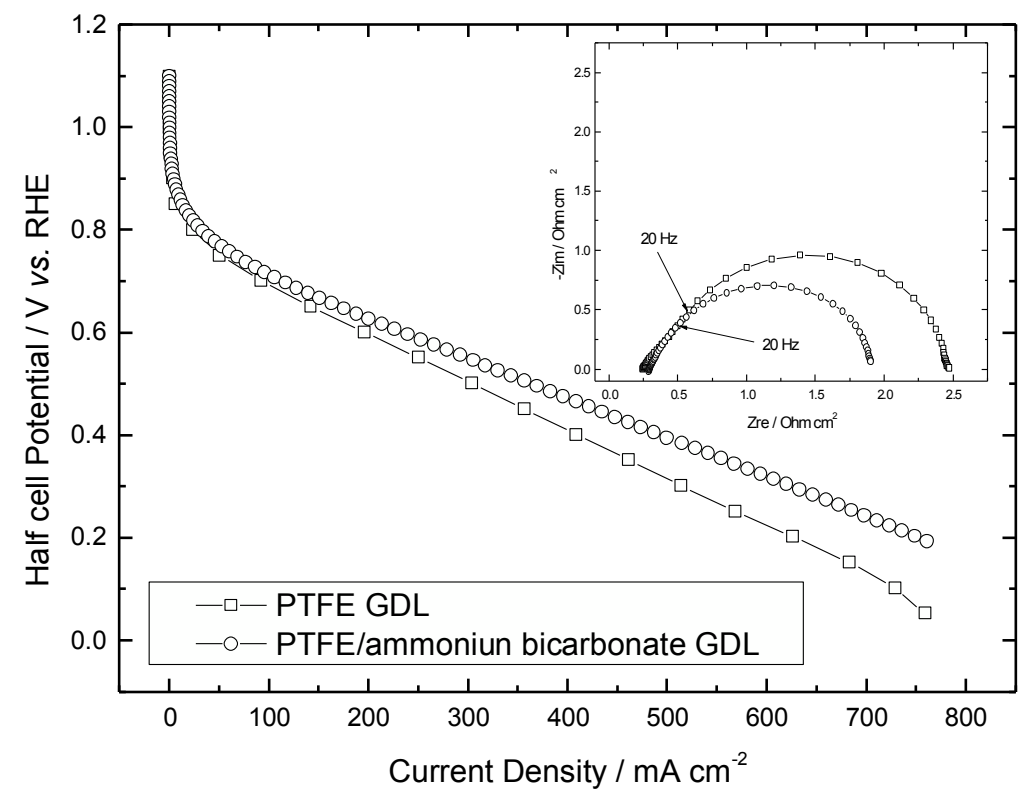

Figure 3: Polarization curves of cathodes made of silver membrane $(0.8 \mu \mathrm{m})$ with PTFE coating and with PTFE/ammonium bicarbonate as hydrophobisation agents under oxygen at $20^{\circ} \mathrm{C}$ in $30 \mathrm{wt} . \% \mathrm{KOH}$ solution and Impedance measurements at 0.8 $\mathrm{V}$ (cell potential) from $10 \mathrm{kHz}$ to $0.01 \mathrm{~Hz}$.

After improving the cathode performance by increasing gas accessibility with PTFE/ammonium bicarbonate as the hydrophobic agent, manganese dioxide was added to increase the electrode activity. As can be seen in Fig. 4, manganese oxide $\left(\mathrm{MnO}_{2}\right)$ improves electrode performance at small and medium overpotential. The cathode with manganese oxide shows a higher mass transport effect than the bare silver porous membrane cathode at potentials below $0.4 \mathrm{~V}$. Performance at high potential are significantly improved from $\sim 30 \mathrm{~mA} \mathrm{~cm}^{-2}$ at $0.8 \mathrm{~V}$ for the bare silver to $\sim 75 \mathrm{~mA} \mathrm{~cm}^{-2}$ at $0.8 \mathrm{~V}$ for the manganese oxide case. It is believed that the significant improvement of performance compare to the bare silver membrane is due to the 
increase in active surface area of catalyst. Tafel analysis of the curves was not performed because of the lack of an extensively developed linear region in the inset plot.

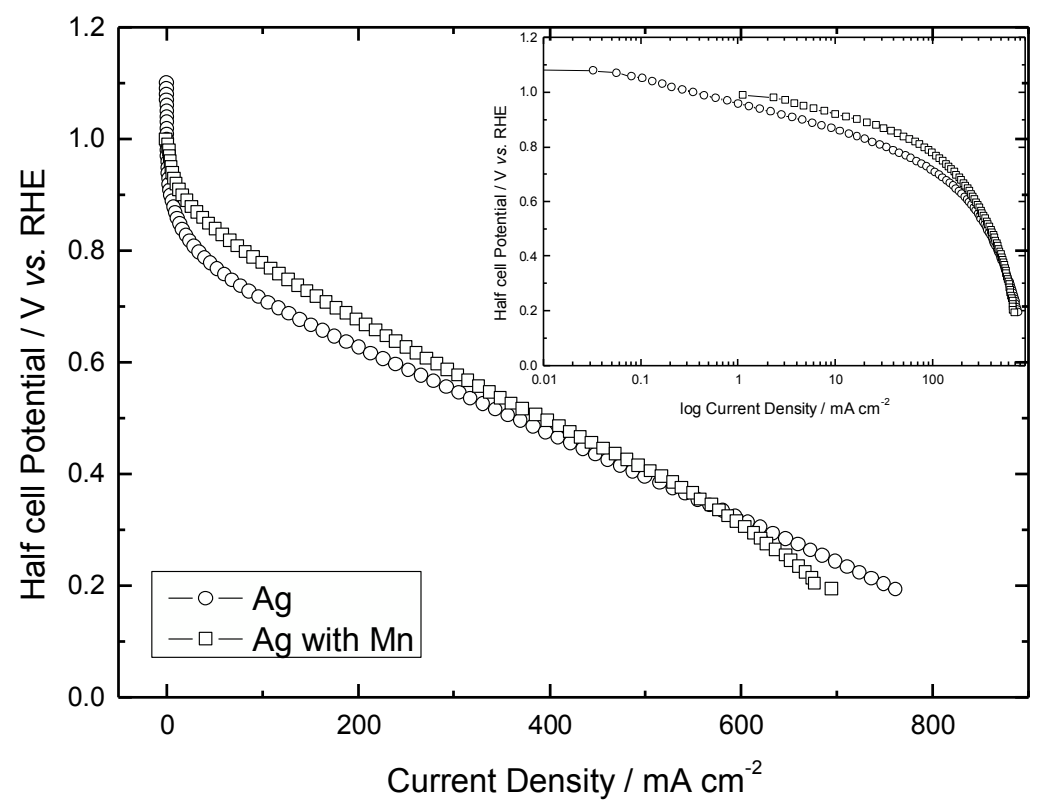

Figure 4: Polarization curves of cathodes made of silver membrane $(0.8 \mu \mathrm{m})$ with PTFE/pore former as hydrophobisation agent and with manganese oxide as added catalysts (loading of $\sim 1.5 \mathrm{mg} \mathrm{cm}^{-2}$ ) in the electrode structure under oxygen at $20^{\circ} \mathrm{C}$ in 30 wt. \% KOH solution (Inset same results shown on a logarithmic current scale).

\subsection{Characterization of silver membranes cathodes with TEFLON AF as hydrophobisation agent}

Fig. 5 shows the performance of different pore size membranes where Teflon AF was used as the hydrophobisation medium on the reactant side of the silver membranes (loading $\sim 1 \mathrm{mg} \mathrm{cm}^{-2}$ ). As can be seen, the $0.45 \mu \mathrm{m}$ pore size membrane outperforms both the 0.80 and $0.20 \mu \mathrm{m}$ pore size membranes starting from $0.8 \mathrm{~V}$ giving quiet good performance at small potential $\left(\sim 530 \mathrm{~mA} \mathrm{~cm}{ }^{-2}\right.$ at $0.4 \mathrm{~V}$ and $\sim 1100 \mathrm{~mA} \mathrm{~cm}{ }^{-2}$ at 0.2 V). It has to be noted that in our previous study, $0.45 \mu \mathrm{m}$ pore size membrane 
performance was much worse. This was attributed to size exclusion of the PTFE particles from the suspension from the inside of the membrane leaving the structure partly flooded with electrolyte leading to a large mass transport effect [25]. This is obviously not the case using Teflon AF, where its solutionproperties allow it to get inside the porous structure leaving a homogeneous coating on the surface of the pores. Interestingly, better performance was obtained with the $\mathrm{PTFE} /$ pore former as hydrophobisation agent (with the $0.8 \mu \mathrm{m}$ pore size membrane) compare to the Teflon AF as hydrophobisation agent $\left(\sim 500 \mathrm{~mA} \mathrm{~cm}^{-2}\right.$ at $0.4 \mathrm{~V}$ and $\sim 820 \mathrm{~mA} \mathrm{~cm}^{-2}$ at $0.2 \mathrm{~V}$ compared to $\sim 440 \mathrm{~mA} \mathrm{~cm}^{-2}$ at $0.4 \mathrm{~V}$ and $\sim 760 \mathrm{~mA} \mathrm{~cm}{ }^{-2}$ at $\left.0.2 \mathrm{~V}\right)$. The better performance obtained with the PTFE/pore former as hydrophobisation agent means that further improvement should be possible with an optimised Teflon AF loading. The wettability of the pores differs with the kind of hydrophobisation agent used. When Teflon AF is used, a uniform coating is deposited within the pores leading to very good hydrophobicity of the structure. In contrast, when PTFE suspension is used, PTFE particles are deposited which may lead to a non-homogeneous hydrophobisation of the structure leading to a slight increase in active surface area compare to the Teflon AF case. This was confirmed by electrolyte uptake measurements performed on $0.8 \mu \mathrm{m}$ pore size silver membranes utilising an untreated membrane, a membrane treated with PTFE suspension and a membrane treated with Teflon AF following the methods described in section 3.1. The total volume of the pores was calculated from the porosity (Table 1) and the volume of the sample used. The volume of the pores filled with electrolyte was calculated from the weight of electrolyte in the structure taking in consideration the density of the $\mathrm{KOH}$ solution at $20^{\circ} \mathrm{C}$. The volume of electrolyte in the untreated silver membrane is calculated to be $102 \%$ of the pore volume - i.e. within the error of this measurement $(\sim 5 \%)$, the entire 
pore volume is filled. This is as might be expected from the wetting behaviour of the electrolyte leading to electrolyte creeping throughout the entire structure of the electrode. When PTFE suspension was used to produce a hydrophobic layer, $36 \%$ of the pore volume was occupied by electrolyte. When Teflon AF was used to make the electrode hydrophobic, only $13 \%$ of the pore volume was filled with electrolyte. We presume the situation is similar to that shown in the cartoon in figure 6. Teflon AF is clearly far superior to PTFE in producing a hydrophobic surface. Similar electrolyte uptake measurements on Teflon AF treated 0.45 and $0.2 \mu \mathrm{m}$ pore size membranes showed that no electrolyte enters the pore structure of these membranes. Hence hydrophobisation of these small pores size membranes by Teflon AF is particularly efficient, whereas hydrophobisation using PTFE suspension does not occur at all [25].

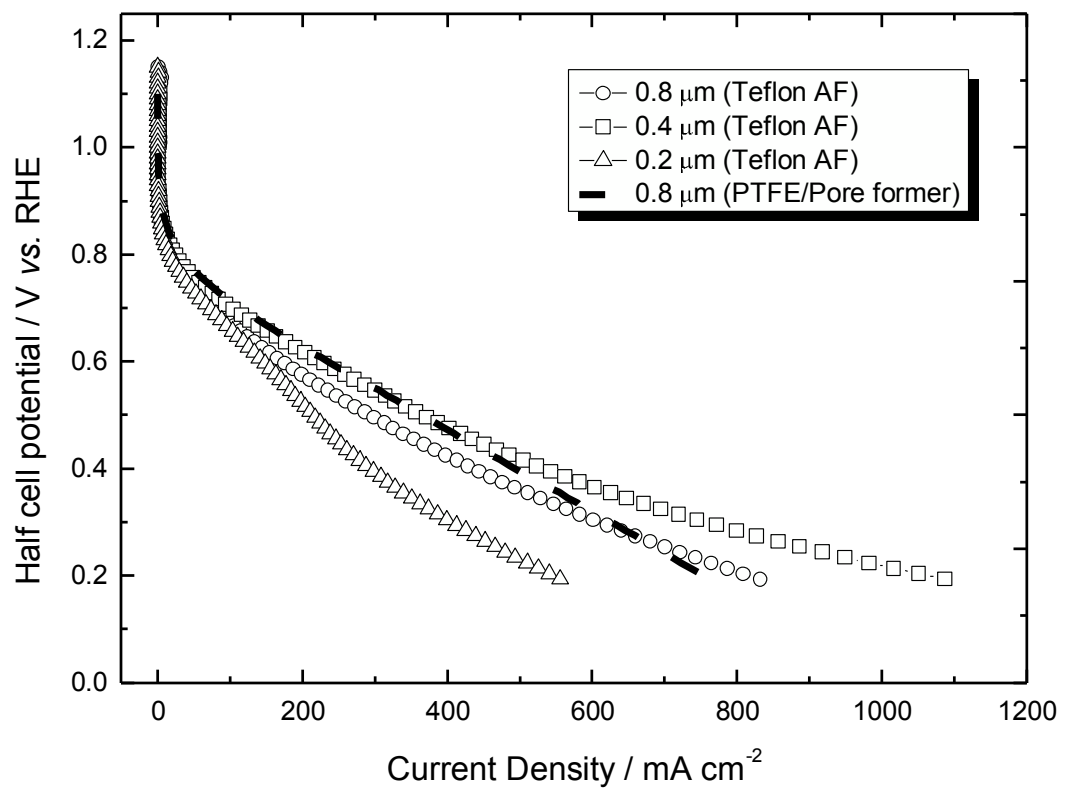

Figure 5: Polarization curves of cathodes made of silver membranes (Pore sizes: 0.2, 0.45 and $0.8 \mu \mathrm{m}$ ) with Teflon AF as hydrophobisation agent and $0.8 \mu \mathrm{m}$ membrane cathode with PTFE/pore former as comparison under oxygen at $20^{\circ} \mathrm{C}$ in $30 \mathrm{wt}$. \% $\mathrm{KOH}$ solution. 

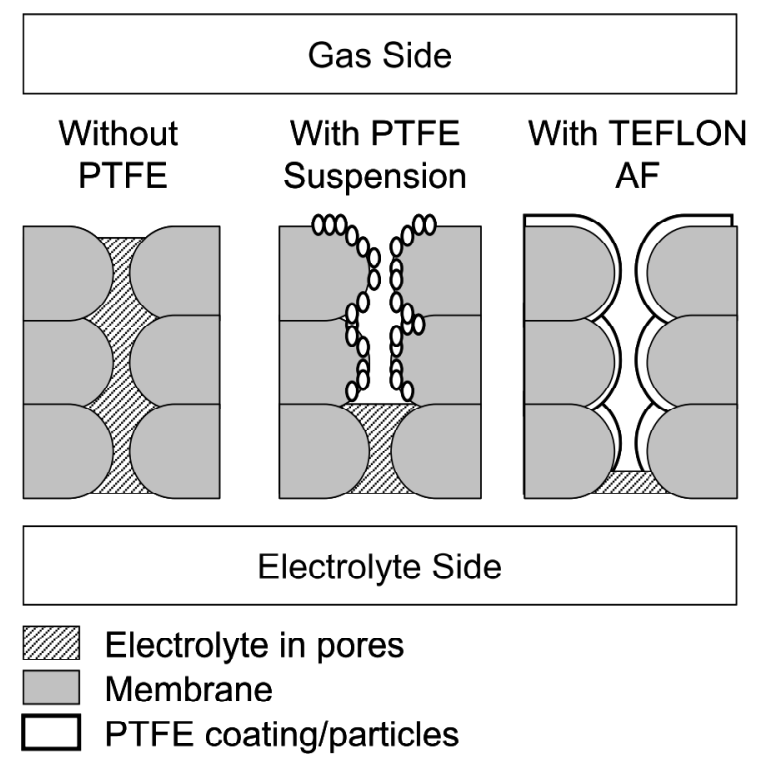

Figure 6: Cartoon showing the deposition of PTFE on the $0.8 \mu \mathrm{m}$ pore size silver membrane and how this may affect wetting of the electrolyte.

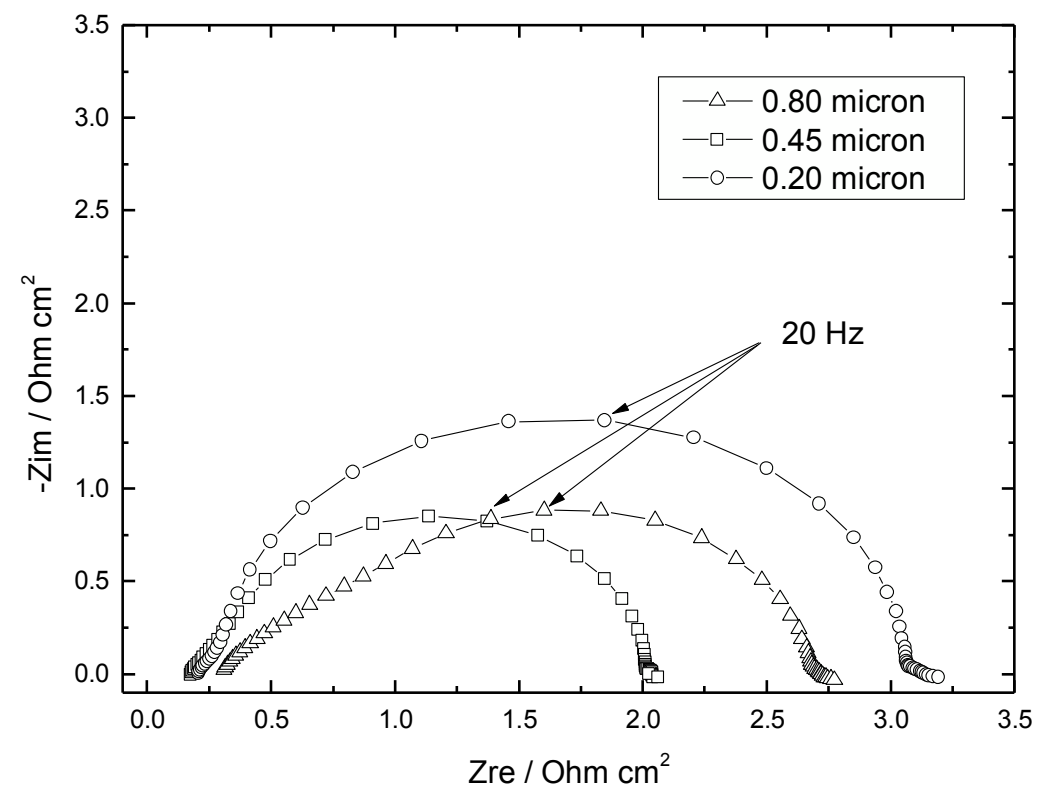

Figure 7: Impedance measurements of cathodes made of silver membranes (Pore sizes: $0.2,0.45$ and $0.8 \mu \mathrm{m}$ ) with Teflon AF as hydrophobisation agent under oxygen and air at $20^{\circ} \mathrm{C}$ in $30 \mathrm{wt}$. $\% \mathrm{KOH}$ solution at $0.8 \mathrm{~V}$ (cell voltage) from $10 \mathrm{kHz}$ to 0.01 $\mathrm{Hz}$. 
Impedance measurements of cathodes made of silver membranes (Pore sizes: 0.2, 0.45 and $0.8 \mu \mathrm{m}$ ) with Teflon AF as hydrophobisation agent are shown in Fig. 7. It can be seen that these cathodes demonstrate the same spectra as those with the PTFE/pore former spectra consisting in a depressed arc at high frequency and a capacitive semi-circle at low frequency. It can be noticed that the depressed high frequency semi-circle, which represents the Ohmic resistance of the electrolyte in active pores (or flooded pores), is much smaller for the 0.2 and $0.45 \mu \mathrm{m}$ pore size membranes than for the $0.8 \mu \mathrm{m}$ pore size membrane. This is due to the increase surface area of the membrane in contact with the electrolyte for the 0.2 and $0.45 \mu \mathrm{m}$ pore size membranes compare to the $0.8 \mu \mathrm{m}$ pore size membrane. The Ohmic resistance appears also to be higher for the $0.8 \mu \mathrm{m}$ pore size membrane than for the 0.2 and $0.45 \mu \mathrm{m}$ pore size membranes which could be due to the Ohmic drop due to the electrolyte inside the structure in the case of the $0.8 \mu \mathrm{m}$ pore size membrane, which is not the case for the 0.2 and $0.45 \mu \mathrm{m}$ pore size membranes shown by the electrolyte uptake measurements. We suspect that the relatively poor performance of the $0.2 \mu \mathrm{m}$ pore size membranes is due to the clogging of some of the pores by the Teflon $\mathrm{AF}^{\dagger}$ Considering the low frequency semi-circle, which represents kinetics of the electrode including mass transport phenomenon, it can be seen that the $0.2 \mu \mathrm{m}$ pore size membrane low frequency semi-circle is much bigger than for the 0.8 and $0.45 \mu \mathrm{m}$ pore size membranes. This could be explained by the relative low porosity of the $0.2 \mu \mathrm{m}$ pore size membrane compare to the other two leading to a more marked mass transport effect and thus lower performance. The $0.45 \mu \mathrm{m}$ pore size membrane

\footnotetext{
${ }^{\dagger}$ We calculate that if the Teflon AF is uniformly coated across the $0.2 \mu \mathrm{m}$ pore size silver membrane then there should be a $\sim 15 \mathrm{~nm}$ layer. However, this might be affected by pooling, and may also preferentially collect at narrow points in the pores leading to their blockage.
} 
demonstrates the best properties: higher surface area compared with the $0.8 \mu \mathrm{m}$ pore size membrane and higher gas accessibility compared with the $0.2 \mu \mathrm{m}$ pore size membrane, given the best performance overall.

In the same way as for the cathode with the PTFE/pore former as hydrophobisation agent, manganese dioxide was added in the electrode structure following the procedure described in the experimental section in order to improve the activity of the electrode. As can be seen in Fig. 8, manganese dioxide improves electrode performance at high and medium potential from open circuit potential to $0.7 \mathrm{~V}$. After $0.7 \mathrm{~V}$, the cathode demonstrates a stronger mass transport effect (probably due to ionic resistance since the hydrophobisation agent for both cathodes is similar) leading to poorer performance than the cathode without manganese oxide at medium and high overpotential.

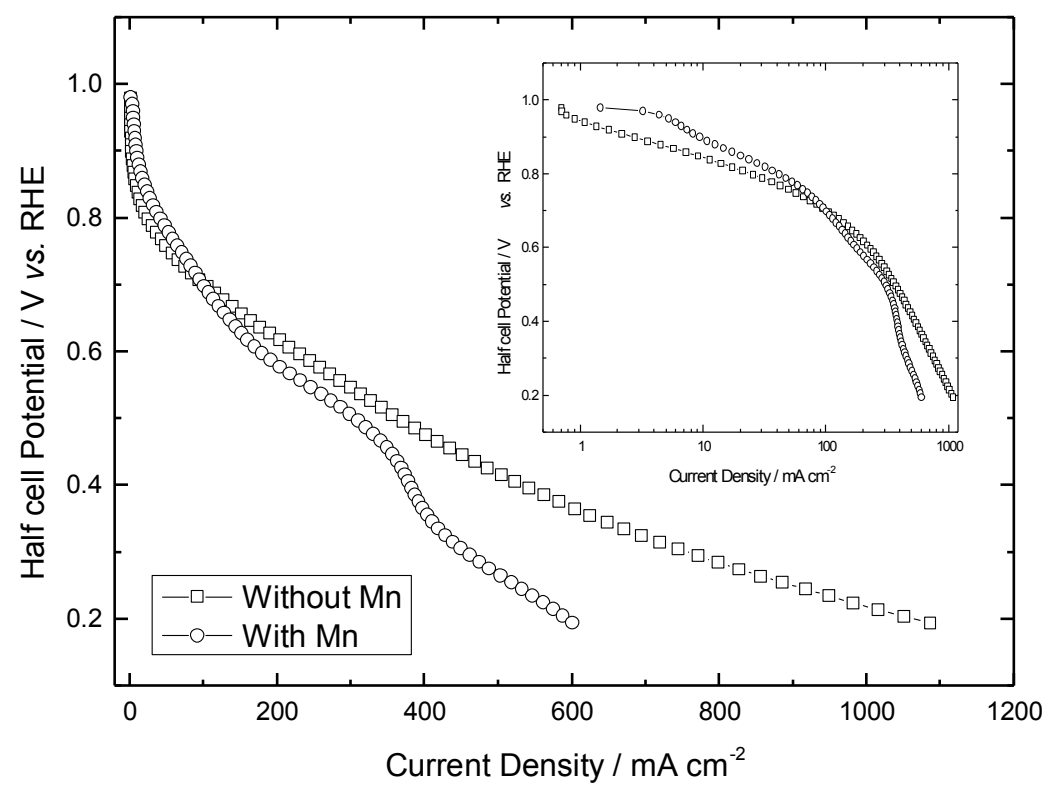

Figure 8: Polarization curves of cathodes made of silver membrane $(0.45 \mu \mathrm{m})$ with Teflon AF as hydrophobisation agent with and without manganese oxide catalyst (loading: $\sim 1.5 \mathrm{mg} \mathrm{cm}^{-2}$ ) under oxygen at $20^{\circ} \mathrm{C}$ in $30 \mathrm{wt} . \% \mathrm{KOH}$ solution. (Inset same results shown on a logarithmic current scale). 
In a similar way, $\mathrm{Pt}$, at a loading of $20 \mu \mathrm{g} \mathrm{cm}^{-2}$, was deposited onto $0.8 \mu \mathrm{m}$ pore size membrane by means of a Pt ink utilising Teflon AF as the hydrophobisation agent as described in the experimental section. Performance improved drastically over all the potential range as can be seen in Fig. $9\left(\sim 295 \mathrm{~mA} \mathrm{~cm}^{-2}\right.$ at $0.6 \mathrm{~V}$ and $\sim 620 \mathrm{~mA} \mathrm{~cm}^{-2}$ at $0.4 \mathrm{~V}$ instead of $\sim 165 \mathrm{~mA} \mathrm{~cm}^{-2}$ at $0.6 \mathrm{~V}$ and $\sim 430 \mathrm{~mA} \mathrm{~cm}^{-2}$ at $0.4 \mathrm{~V}$ ). The improvement in performance is quiet remarkable when considering the very low $\mathrm{Pt}$ loading. Comparing impedance measurements from both cathodes (Fig. 8 Inset), it appears that both the low and high frequency semi-circles are decreased with the addition of Pt. This is believed to be due to an increase of catalyst activity and surface area respectively, improving mostly the kinetics of the electrode. Interestingly, no mass transport effect is shown upon addition of $\mathrm{Pt}$ which was not the case when a similar comparison was made with a $0.45 \mu \mathrm{m}$ pore size membrane with Teflon AF as hydrophobisation agent (results not shown). For the latter comparison, performance dropped in the same way as for with the manganese oxide (Fig.8).

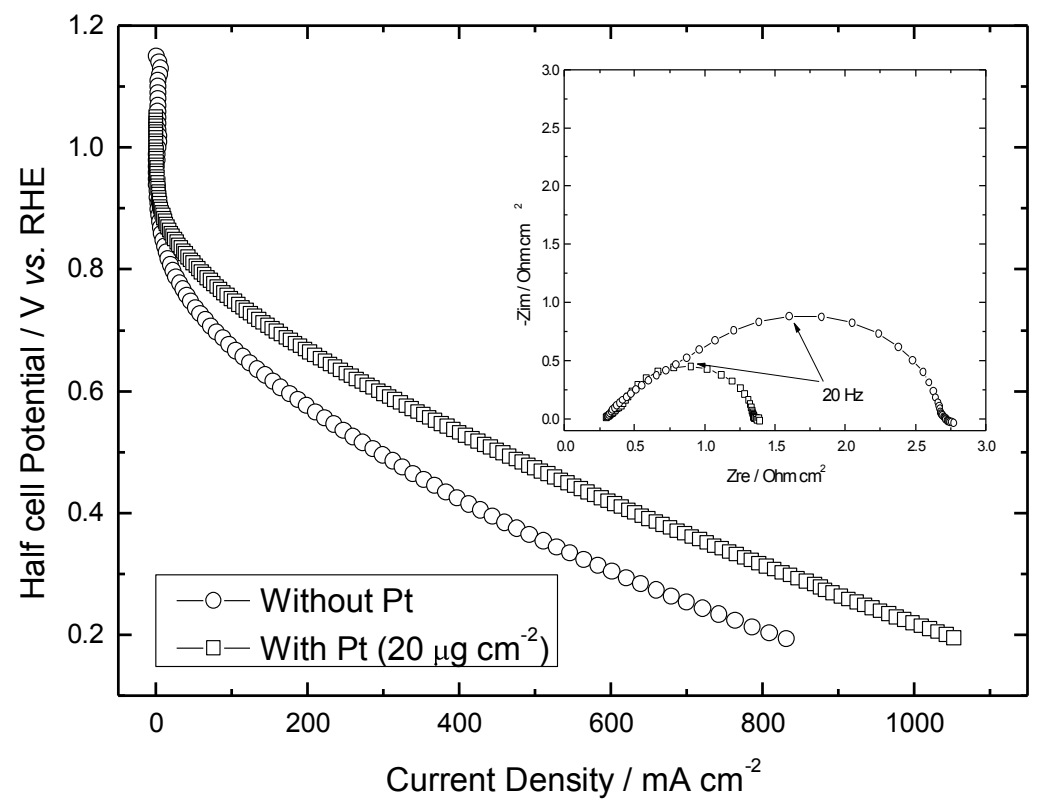


Figure 9: Polarization curves of cathodes made of silver membranes $(0.8 \mu \mathrm{m})$ with Teflon AF as hydrophobisation agent under oxygen at $20^{\circ} \mathrm{C}$ in 30 wt. $\% \mathrm{KOH}$ solution and impedance measurements at $0.8 \mathrm{~V}$ (cell voltage) from $10 \mathrm{kHz}$ to 0.01 $\mathrm{Hz}$.

Table 2 summarizes the formulation and performance of each of the cathode presented in Fig. 3, 4, 5, 8 and 9 under oxygen at $20^{\circ} \mathrm{C}$ in 30 wt. $\% \mathrm{KOH}$ solution.

\begin{tabular}{|c|c|c|c|c|}
\hline $\begin{array}{c}\text { Cathode } \\
\text { from figure }\end{array}$ & $\begin{array}{c}\text { Ag membrane } \\
\text { type }(\mu \mathrm{m})\end{array}$ & $\begin{array}{c}\text { hydrophobic agent } \\
\text { type }\end{array}$ & $\begin{array}{c}\text { Extra Catalyst } \\
\text { type }\end{array}$ & $\begin{array}{c}\text { Current density } \\
\text { at } 0.8 \mathrm{~V}(\mathrm{~mA} \\
\left.\mathrm{cm}^{-2}\right)\end{array}$ \\
\hline 3 & 0.8 & PTFE/pore former & None & 30 \\
\hline 4 & 0.8 & PTFE/pore former & $\mathrm{MnO}_{2}$ & 75 \\
\hline 5 & 0.45 & Teflon AF & $\mathrm{None}$ & 24 \\
\hline 8 & 0.45 & Teflon AF & $\mathrm{MnO}_{2}$ & 42 \\
\hline 9 & 0.8 & Teflon AF & $\mathrm{Pt}$ & 56 \\
\hline
\end{tabular}

Table 2: Formulation and performance of cathode developed in this study.

Testing of the new cathode in a $4 \mathrm{~cm}^{2}$ cylindrical Hydrogen-air fuel cell was also performed utilising the silver membrane $(0.8 \mu \mathrm{m}$ pore size with Teflon AF as hydrophobisation agent) with $\mathrm{Pt}\left(20 \mu \mathrm{g} \mathrm{cm}^{-2}\right)$ as cathode under passive air breathing mode. Under these conditions, the silver membrane functions as both mechanical support, sole current collector ( $>1 \mathrm{~cm}$ maximum current path), and electrocatalyst. For comparison, the previous cathode design presented in [25] was also plotted (Fig. 10). Both systems were tested in the same cell and under the same conditions (atmospheric pressure) for 1 hour until steady state performance was obtained. As can be seen from Fig. 10, performance of the cathode with the Teflon AF as hydrophobisation agent is better than those of the old cathode design having approximately the same Pt loading. The cathode design attains a peak power density of $65 \mathrm{~mW} \mathrm{~cm}^{-2}$ at a cell voltage of $0.4 \mathrm{~V}$ under passive self-breathing operation showing a $30 \%$ increase in power density compared to the previous cathode design. This is an impressive performance considering that no backpressure or forced air convection is applied, and the cathode 
is open to the laboratory air. Cathode performance is mostly improved at high current densities showing the beneficial effect of the Teflon AF as hydrophobisation agent compared to the PTFE suspension. Some reduction in performance compared to the half-cell results is seen and this could be explained by the presence of the spacer between the cathode and the anode. Comparison of impedance spectra (not shown) did not show any increase in Ohmic resistance between the half-cell and fuel cell mode but an increase in the low-frequency kinetic semi-circle. This could be due to the higher resistance to species $\left(\mathrm{H}_{2} \mathrm{O}, \mathrm{OH}^{-}\right)$to migrate from anode to cathode induced by the spacer (since there was no difference in air flow rate or electrode structure).

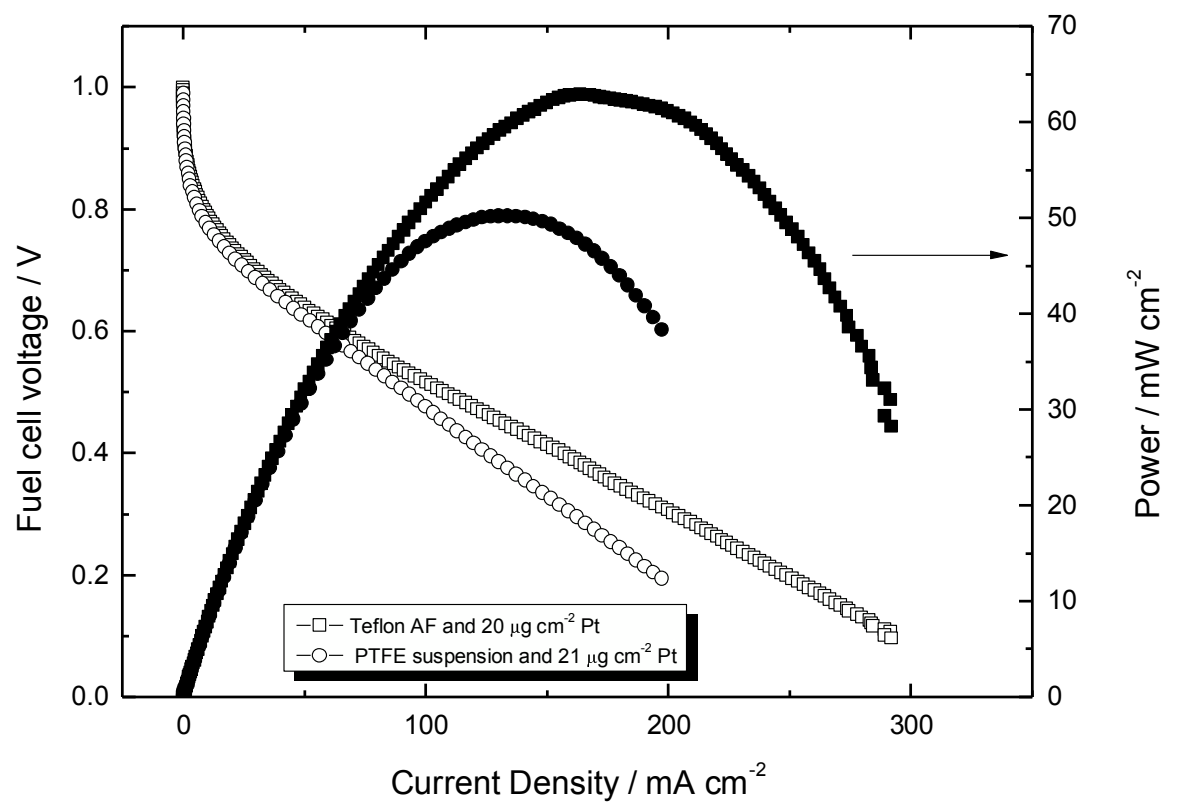

Figure 10: Hydrogen-air fuel cell test of silver membranes $(0.8 \mu \mathrm{m})$ with Teflon AF as hydrophobisation agent with Pt $\left(20 \mu \mathrm{g} \mathrm{cm}^{-2}\right)$ utilising $30 \mathrm{wt} . \% \mathrm{KOH}$ solution as electrolyte and $1 \mathrm{~mm}$ electrode separation at $20^{\circ} \mathrm{C}$. Pt on carbon paper $\left(0.4 \mathrm{mg} \mathrm{cm}^{-2}\right)$ used as anode. For comparison, results from the previous design is shown using PTFE suspension as hydrophobisation agent with $\operatorname{Pt}\left(21 \mu \mathrm{g} \mathrm{cm}^{-2}\right)$. 


\section{Conclusions}

Cathodes for alkaline fuel cells have been developed using porous silver membranes as electrode substrates which fulfil both electrocatalytic function, mechanical support and a means of current collection. Performance of the cathodes has been improved by a two step approach where first the hydrophobic layer was improved by increasing oxygen accessibility. The second step was to improve electrode activity by putting in the membrane structure an extra catalyst $\left(\mathrm{MnO}_{2}\right.$ or $\left.\mathrm{Pt}\right)$ where manganese oxide $\left(\mathrm{MnO}_{2}\right)$ demonstrated good catalytic activity towards the oxygen reduction reaction. Manganese oxide offers a good alternative catalyst for future studies being much less expensive than silver or platinum for alkaline fuel cells. The $0.8 \mu \mathrm{m}$ pore size membrane showed the best performance compared to the 0.2 and $0.45 \mu \mathrm{m}$ pore size membranes which suffer from mass transport effects.. The membrane with $0.8 \mu \mathrm{m}$ pore size appeared to offer the best balance between surface area and porosity and produced the highest performance even with extra catalyst in the structure. Performance obtained with $0.8 \mu \mathrm{m}$ pore size membrane, Teflon AF as hydrophobisation agent and $\mathrm{Pt}$ as an extra catalyst is quite good $\left(\sim 295 \mathrm{~mA} \mathrm{~cm} \mathrm{~cm}^{-2}\right.$ at 0.6 $\mathrm{V}$ and $\sim 620 \mathrm{~mA} \mathrm{~cm}^{-2}$ at $\left.0.4 \mathrm{~V}\right)$ considering the relative low Pt loading $\left(20 \mu \mathrm{g} \mathrm{cm}^{-2}\right)$. In a hydrogen fuel cell mode, this cathode showed improved performance compare to a previous cathode design giving a very good power density of $65 \mathrm{~mW} \mathrm{~cm}^{-2}$ under passive self-breathing operation. It is believed by the authors that the Teflon AF deposition and loading could be further improved leading to higher oxygen accessibility and therefore better performance. Teflon AF has been proven to be a good material for the hydrophobisation agent when used with silver membranes where there is no need for sintering when using this material, which speeds up and simplifies electrode fabrication. On the negative side, Teflon AF is not a cheap 
materials $(\sim 60 \$ / \mathrm{g})$ but only a small amount (typically $\left.\sim 1 \mathrm{mg} \mathrm{cm}^{-2}\right)$ is enough to obtain a good gas diffusion layer and would cost $\$ 1.5$ for a $25 \mathrm{~cm}^{2}$ electrode.

\section{References}

[1] M. Duerr, S. Gair, A. Cruden, and J. McDonald, Dynamic electrochemical model of an alkaline fuel cell stack. J. Power Sources 171 (2007) 1023-1032.

[2] T. Hejze, J.O. Besenhard, K. Kordesch, M. Cifrain, and R.R. Aronsson, Current status of combined systems using alkaline fuel cells and ammonia as a hydrogen carrier. J. Power Sources 176 (2008) 490-493.

[3] G. Mulder, P. Coenen, A. Martens, and J. Spaepen, The development of a $6 \mathrm{~kW}$ fuel cell generator based on alkaline fuel cell technology. Int. J. Hydrogen Energy 33 (2008) 3220-3224.

[4] I. Verhaert, M. De Paepe, and G. Mulder, Thermodynamic model for an alkaline fuel cell. J. Power Sources 193 (2009) 233-240.

[5] G.F. McLean, T. Niet, S. Prince-Richard, and N. Djilali, An assessment of alkaline fuel cell technology. Int. J. Hydrogen Energy 27 (2002) 507-526.

[6] K. Strasser, The design of alkaline fuel cells. J. Power Sources 29 (1990) 149166.

[7] J.R. Varcoe, An electron-beam-grafted ETFE alkaline anion-exchange membrane in metal-cation-free solid-state alkaline fuel cells. Electrochem. commun. 8 (2006) 839.

[8] F. Bidault, D.J.L. Brett, P.H. Middleton, and N.P. Brandon, Review of gas diffusion cathodes for alkaline fuel cells. J. Power Sources 187 (2009) 39-48.

[9] M. Cifrain, and K.V. Kordesch, Advances, aging mechanism and lifetime in AFCs with circulating electrolytes. J. Power Sources 127 (2004) 234-242.

[10] K. Tomantschger, F. McClusky, L. Oporto, A. Reid, and K. Kordesch, Development of low cost alkaline fuel cells. J. Power Sources 18 (1986) 317335.

[11] B.B. Blizanac, P.N. Ross, and N.M. Markovic, Oxygen electroreduction on $\operatorname{Ag}\left(\begin{array}{ll}1 & 1\end{array}\right.$ ): The pH effect. Electrochimica Acta 52 (2007) 2264-2271. 
[12] M. Chatenet, L. Genies-Bultel, and M. Aurousseau, Oxygen reduction on silver catalysts in solutions containing various concentrations of sodium hydroxide-comparison with platinum. J. Applied electrochem. 32 (2002) 1131-1140.

[13] V. Hacker, E. Wallnofer, W. Baumgartner, T. Schaffer, J.O. Besenhard, H. Schrottner, and M. Schmied, Carbon nanofiber-based active layers for fuel cell cathodes - preparation and characterization. Electrochem. Commun. 7 (2005) 377-382.

[14] A.E.S. Sleightholme, J.R. Varcoe, A.R. Kucernak, Oxygen reduction at the silver/hydroxide-exchange membrane interface. Electrochem. Commun. 10 (2008) 151-155.

[15] N. Furuya, and H. Aikawa, Comparative study of oxygen cathodes loaded with $\mathrm{Ag}$ and Pt catalysts in chlor-alkali membrane cells. Electrochimica Acta 45 (2000) 4251-4256.

[16] I. Moussallem, et al. Chlor-alkali electrolysis with oxygen depolarized cathodes: history, present status and future prospects. J.Appl.Electrochem. 38 (2008) 1177-1194.

[17] K. Smrcek, J. Beran, and J. Jandera, The silver catalyst in the hydrophobic oxygen electrode. J. Power Sources 2 (1978) 273-286.

[18] M. Al-Saleh, Effect of carbon dioxide on the performance of Ni/PTFE and Ag/PTFE electrodes in an alkaline fuel cell. J. Applied Electrochem. 24 (1994) $575-580$.

[19] F. Bidault, D.J.L Brett, P.H. Middleton, N. Abson and N.P. Brandon, A new application for nickel foam in alkaline fuel cells. Int. J. Hydrogen Energy 34 (2009) 6799-6808.

[20] F. Bidault, D.J.L Brett, P.H. Middleton, N. Abson and N.P. Brandon, An improved cathode for alkaline fuel cells. Int. J. Hydrogen Energy 35 (2010) 1783-1788.

[21] O. Akhavan, and E. Ghaderi, Bactericidal effects of Ag nanoparticles immobilized on surface of $\mathrm{SiO} 2$ thin film with high concentration. Current Applied Physics 9 (2009) 1381-1385.

[22] S.A. Glazier, Autoflurosecence detection of Escherichia coli on silver membrane filters. J. Microbiological Methods 20 (1994) 23. 
[23] Y. Lv, H. Liu, Z. Wang, S. Liu, L. Hao, Y. Sang, D. Liu, J. Wang, and R.I. Boughton, Silver nanoparticle-decorated porous ceramic composite for water treatment. J. Membrane Science 331 (2009) 50-56.

[24] A. Pérez Padilla, Synthesis and water ultrafiltration properties of silver membrane supported on porous ceramics. Desalination 114 (1997) 203.

[25] I. Sondi, and B. Salopek-Sondi, Silver nanoparticles as antimicrobial agent: a case study on E. coli as a model for Gram-negative bacteria. J. Colloid and Interface Science 275 (2004) 177-182.

[26] F. Bidault and A. Kucernak, A novel cathode for alkaline fuel cells based on a porous silver membrane.J. Power Sources 195 (2010) 2549-2556.

[27] F.H.B. Lima, M.L. Calegaro, and E.A. Ticianelli, Electrocatalytic activity of manganese oxides prepared by thermal decomposition for oxygen reduction. Electrochimica Acta 52 (2007) 3732-3738.

[28] M.L. Calegaro, F.H.B. Lima, and E.A. Ticianelli, Oxygen redution on nanosized manganese oxide particles dispersed on carbon in alkaline solutions. J. Power Sources 158 (2006) 735-739.

[29] A.K.H. Nohman, H.M. Ismail, and G.A.M. Hussein, Thermal and chemical events in the decomposition course of manganese coumpounds. J Anl. Appl. Pyrol. 34 (1995) 265-278.

[30] S. Srinivasan, Fuel Cells: From Fundamentals to Applications, Springer, 2006, pp.692.

[31] D. Thiele, and A. Züttel, Electrochemical characterisation of air electrodes based on $\mathrm{La} 0.6 \mathrm{Sr} 0.4 \mathrm{CoO} 3$ and carbon nanotubes. J. Power Sources 183 (2008) 590-594.

[32] P.-L. Cabot, F. Alcaide, and E. Brillas, Hydrogen reaction at open circuit in alkaline media on Pt in a gas-diffusion electrode. J. Electroanalytical Chem. 626 (2009) 183-191.

[33] CRC, Handbook of chemistry and physics, $61^{\text {st }}$ Edition, 1980-1982. 
Figure 2
Click here to download Figure(s): figure 2.eps

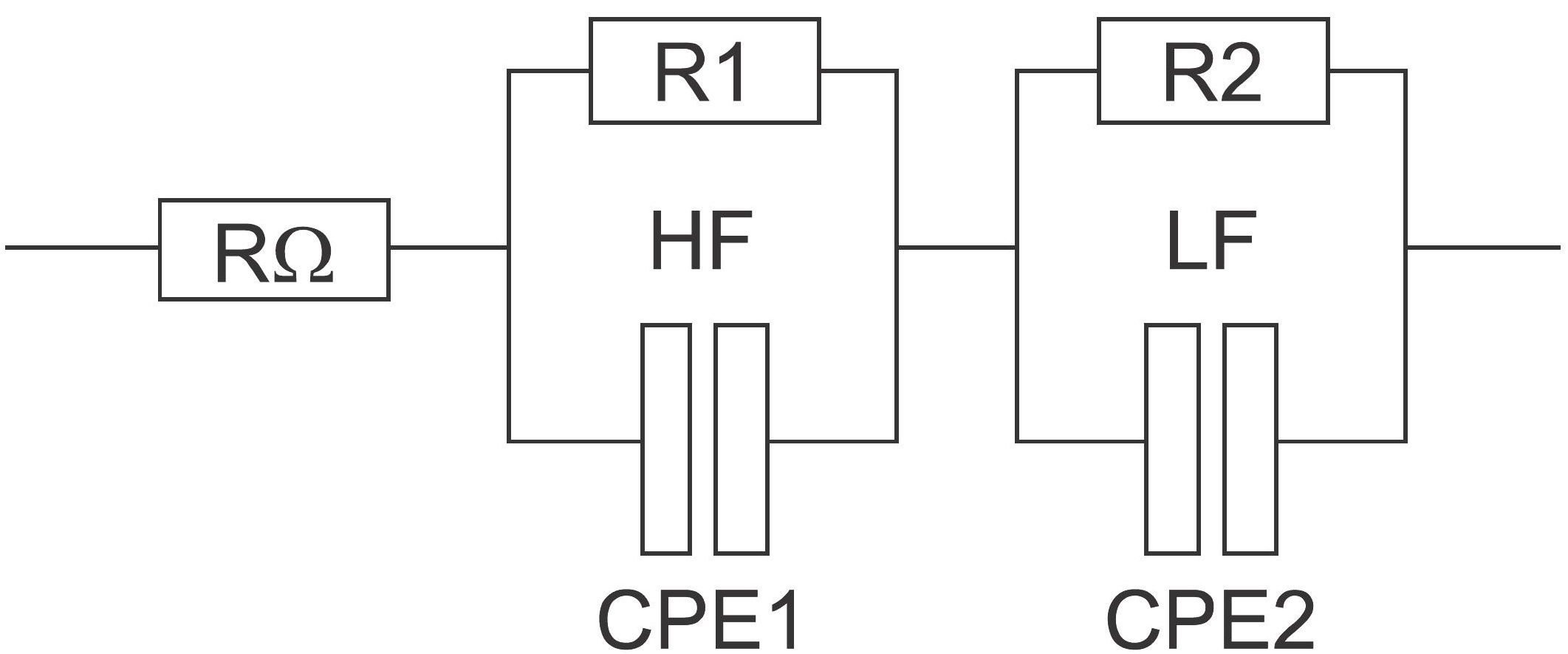




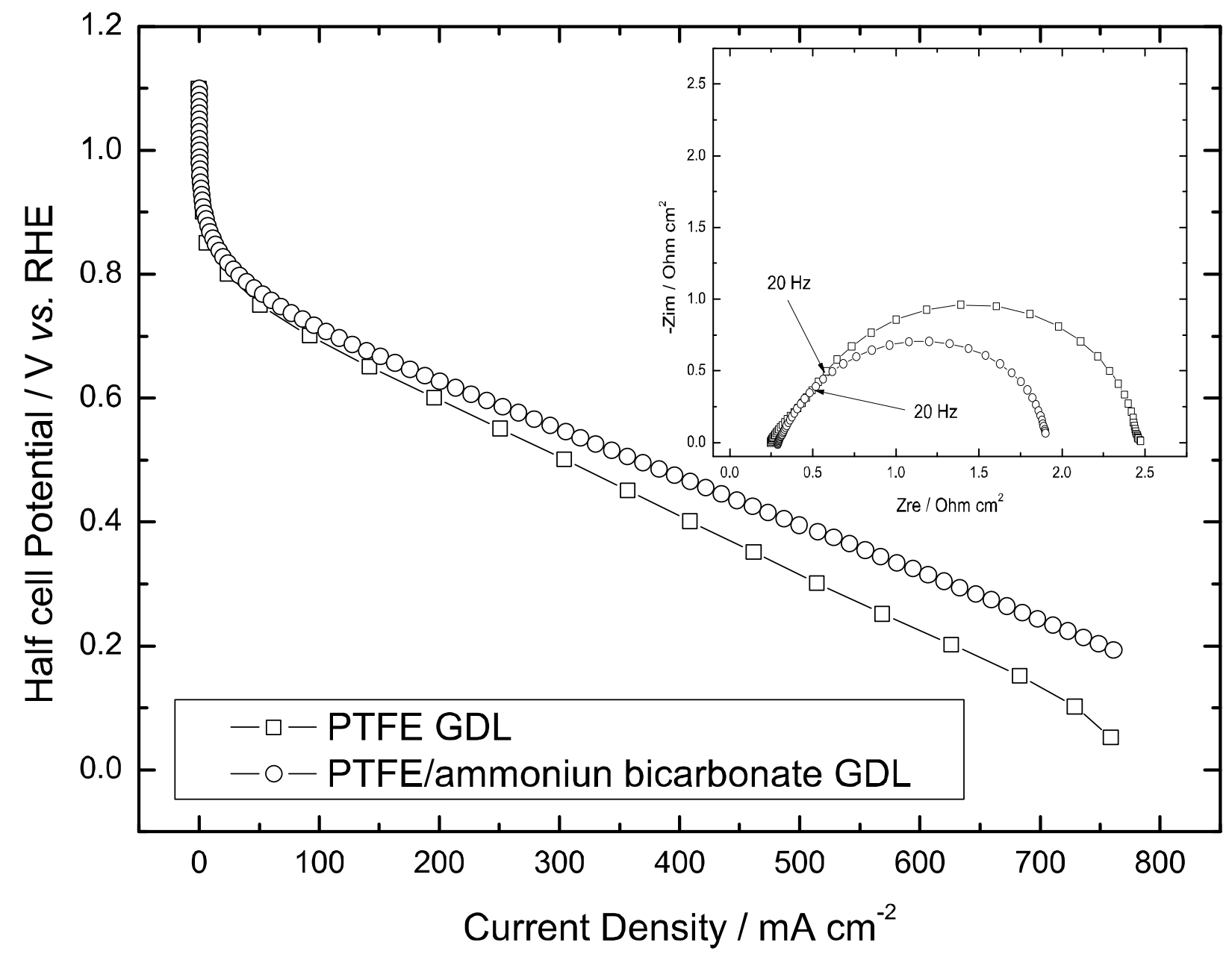




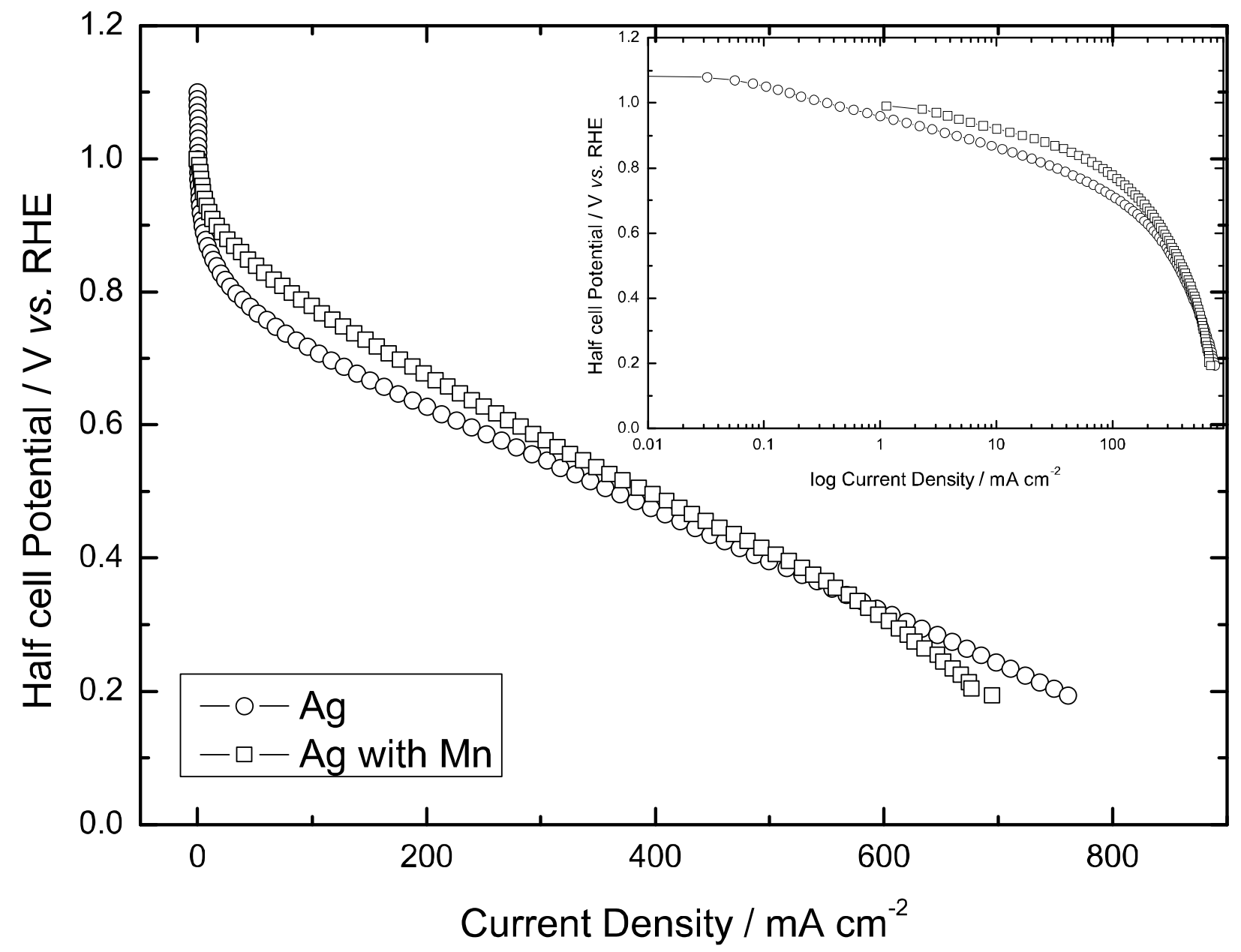




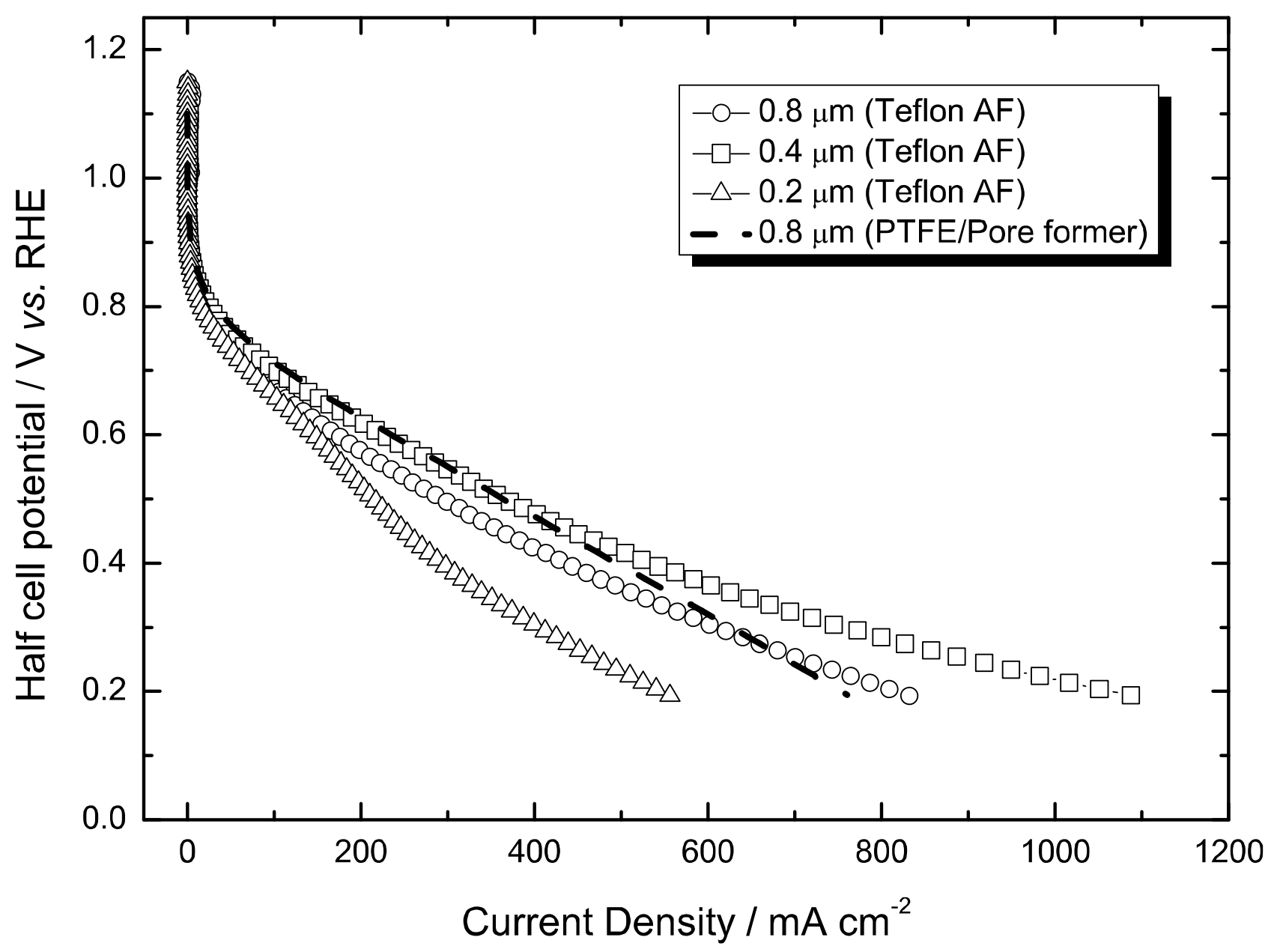


Click here to download Figure(s): figure 6.eps

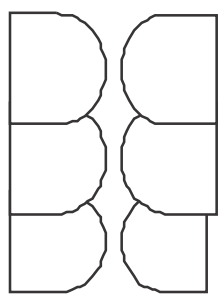




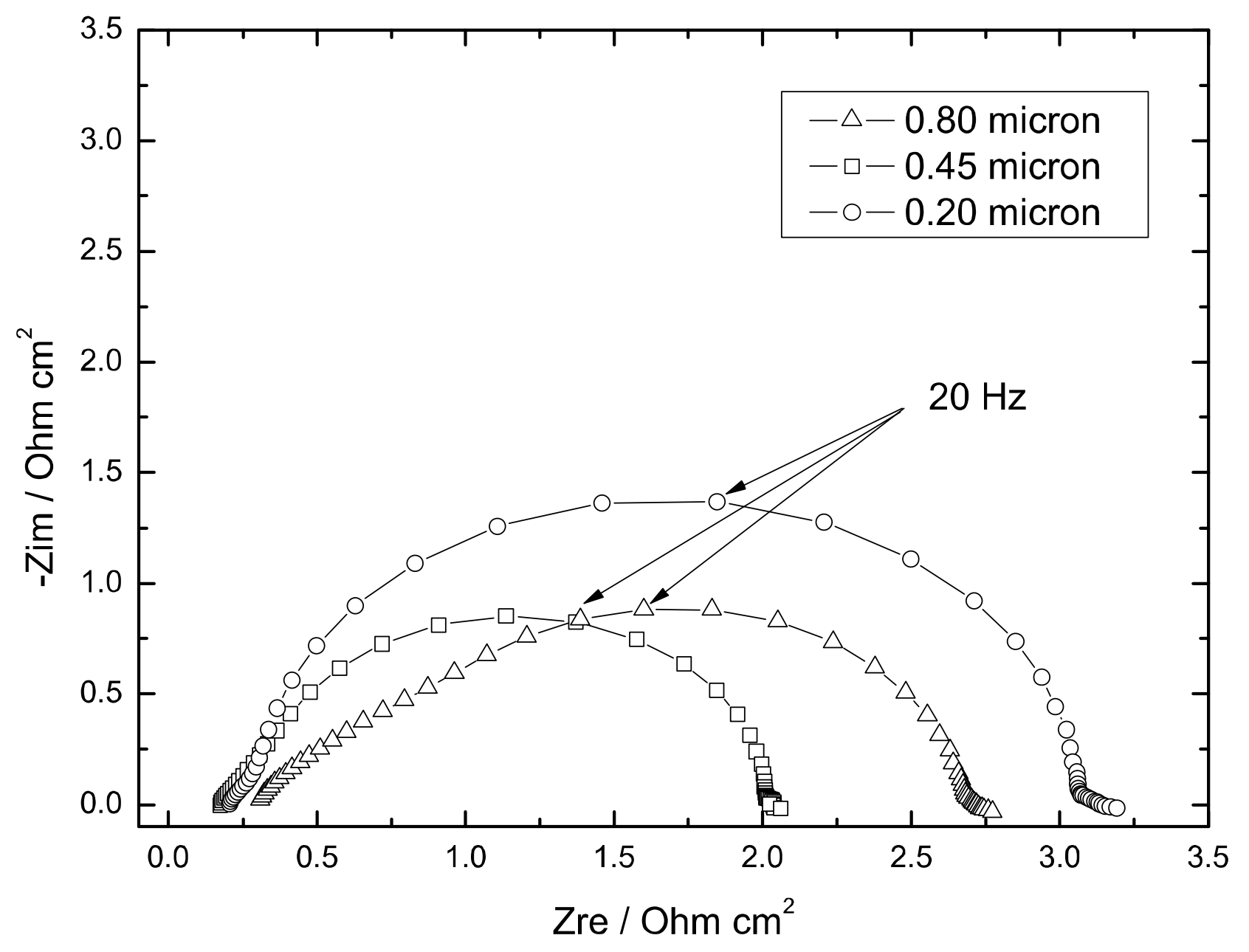




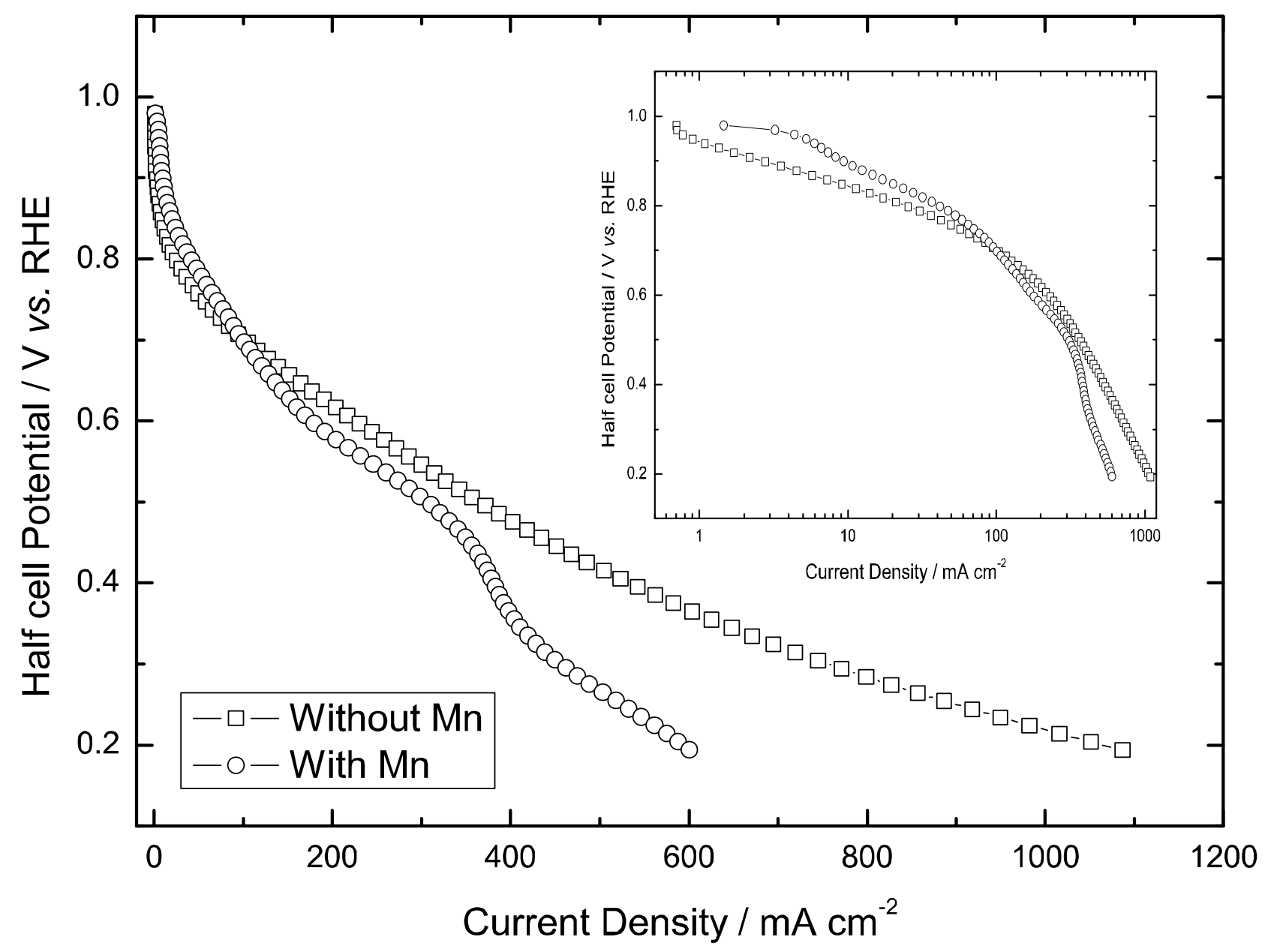




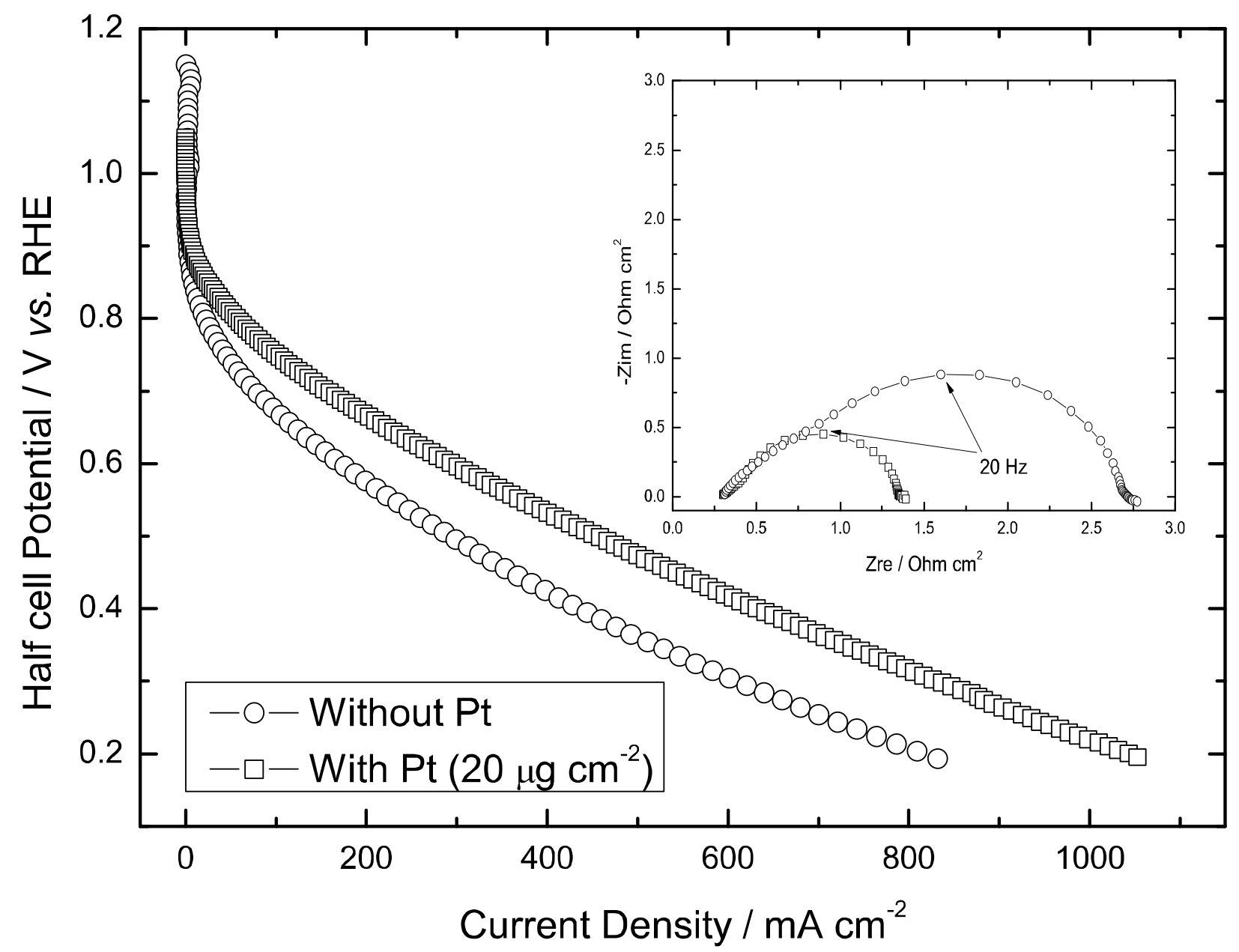




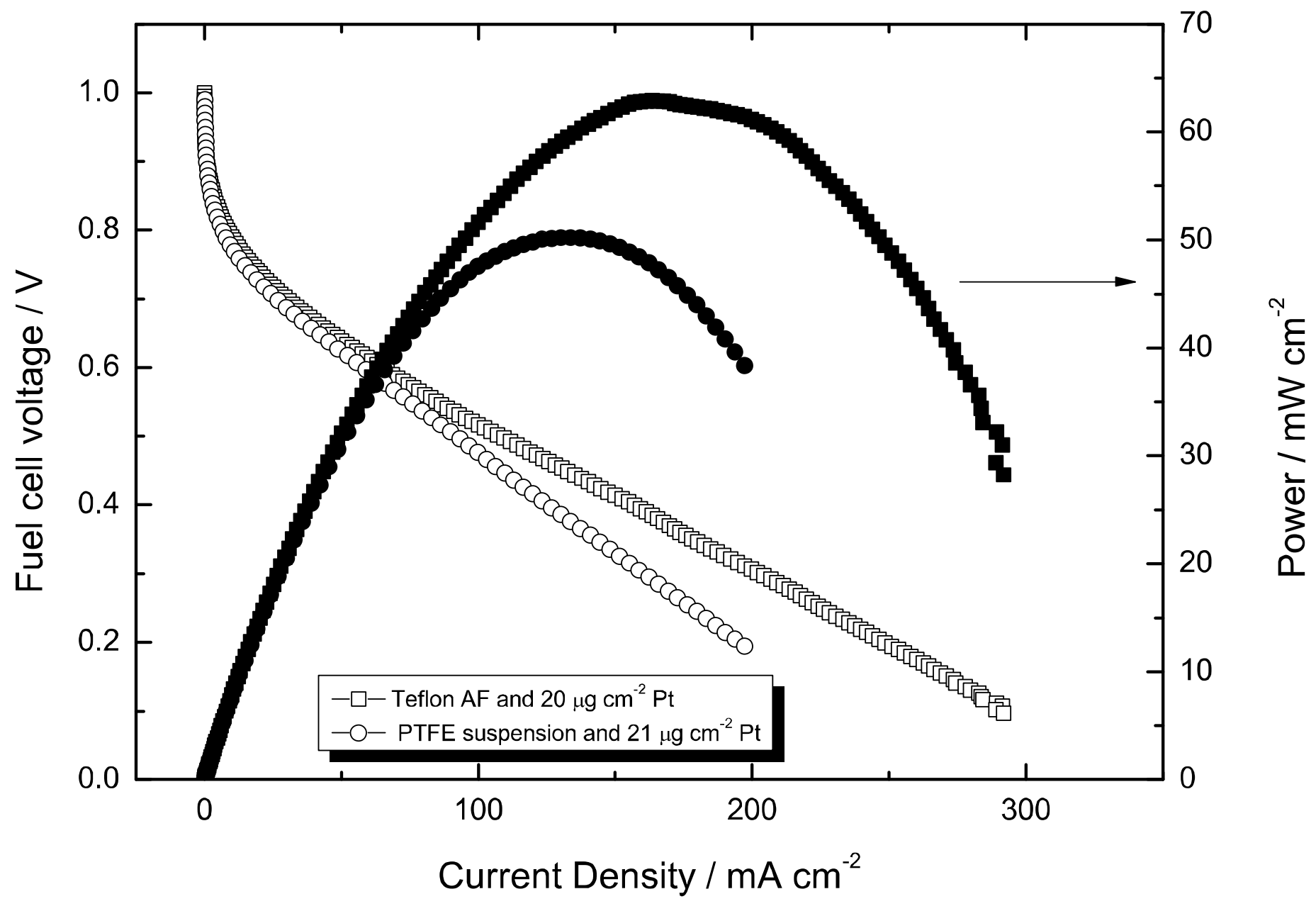




\section{Manuscript with markup showing changes}

Click here to download Supplementary Materials: AgPorousMen2 - secondReviewed2 - submission - with markup.doc 